\title{
GLYCEMIC INDEX OF PRE-EXERCISE MEAL IN DIABETES MELLITUS: A SYSTEMATIC REVIEW
}

\author{
ÍNDICE GLICÊMICO DA REFEIÇÃO PRÉ-EXERCÍCIO NO DIABETES MELLITUS: UMA REVISÃO SISTEMÁTICA \\ ÍNDICE GLICÉMICO DE COMIDA PRE-EJERCICIO EN LA DIABETES MELLITUS: UNA REVISIÓN SISTEMÁTICA
} \section{S}

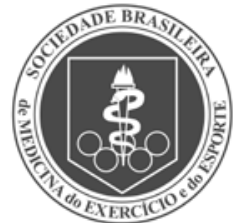

SYSTEMATIC REVIEW ARTICLE ARTIGo de REVISÃo SISTEMÁtICA Artículo de ReVISIÓN Sistemática

\author{
Valéria Cristina de Faria' \\ (Physical Educator) \\ Luciana Moreira Lima² \\ (Biochemical pharmacist) \\ Danielle Aparecida Gomes Pereira \\ (Physiotherapist) \\ 1. Universidade Federal de Minas \\ Gerais, Posgraduate Program \\ in Rehabilitation Sciences, Belo \\ Horizonte, Minas Gerais, Brazil. \\ 2. Universidade Federal de Viçosa, \\ Department of Medicine and \\ Nursing, Viçosa, MG, Brazil.
}

\section{Correspondence:}

Danielle Aparecida Gomes Pereira, Universidade Federal de Minas Gerais, Department of Physiotherapy. Av. Antônio Carlos, 6.627, Pampulha, Belo Horizonte, Minas Gerais, Brazil. 31270-901 danielleufmg@gmail.com

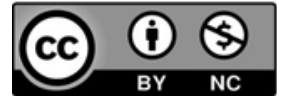

\begin{abstract}
Physical exercise and diet quality are essential for glycemic control of diabetic patients, but consideration must be given to the risk of hypoglycemia in response to exercise. Therefore this study aims at 1) conducting a systematic review of the glycemic index (Gl) of the pre-exercise meal and of glycemic behavior during and after aerobic exercise in diabetic subjects, and 2) discussing the safest and most appropriate pre-exercise nutritional guidance for this population. In accordance with the Preferred Reporting Items for Systematic Reviews and Meta-Analyses (PRISMA), two researchers independently undertook a systematic search. A third researcher participated in the selection of articles due to the presence of discrepancies. We selected two studies which both suggest that a low glycemic index (GI) meal is the best pre-exercise option, one of which suggests that the optimal time for food intake is 30 minutes before exercise. However, these results are not sufficient to define a clinical conduct, and other studies are needed to elucidate whether $\mathrm{Gl}$ is a relevant parameter for pre- and post-exercise clinical monitoring of patients with diabetes mellitus (DM), particularly as regards to the different guidelines for type 1 and type 2 DM. Level of Evidence Il; Prognostic Study.
\end{abstract}

Keywords: Diabetes mellitus; Aerobic exercise; Feeding behavior; Carbohydrate; Glycemic index; Hypoglycemia.

\section{RESUMO}

Exercício físico e qualidade da alimentação são fundamentais para o controle glicêmico dos pacientes diabéticos, poréménecessário considerar o risco de hipoglicemia em resposta ao exercício. Dessa forma, os objetivos deste estudo são: 1) conduzir uma revisão sistemática sobre o indice glicêmico (IG) da refeição pré-exercício e do comportamento glicêmico durante e após exercício aeróbico em diabéticos e 2) discutir qual orientação nutricional pré-exercício seria mais adequada e segura nessa população. Em concordância com os Itens de Relatório Preferidos para Revisões Sistemáticas e Metanálises (PRISMA), dois pesquisadores independentes realizaram uma busca sistemática. Um terceiro pesquisador participou da seleção dos artigos por causa da presença de discrepâncias. Foram selecionados dois estudos e ambos sugerem que a refeição de baixo índice glicêmico (IG) é a melhor opção pré-exercício, e um deles sugere que o tempo ideal para ingestão alimentar é 30 minutos antes do exercício. Porém, esses resultados não são suficientes para definir uma conduta clínica, sendo necessários outros estudos para elucidar se o IG éum parâmetro relevante para o monitoramento clínico do paciente com diabetes mellitus (DM) antes e depois do exercício, principalmente com relação às orientações distintas às do DM tipo 1 e tipo 2. Nível de evidência ll; Estudo Prognóstico.

Descritores: Diabetes mellitus; Exercício aeróbico; Comportamento alimentar; Carboidratos; Indice glicêmico; Hipoglicemia.

\section{RESUMEN}

Ejercicio físico y la calidad de los alimentos son esenciales para el control glucémico de la diabetes, sin embargo, es necesario prestar atención al riesgo de hipoglucemia en respuesta al ejercicio. Por lo tanto, los objetivos de este estudio son: 1) Realizar una revisión sistemática del índice glucémico (IG) de la comida previa al ejercicio y el comportamiento de la glucemia durante y después del ejercicio aeróbico en los diabéticos y 2) discutir cuál orientación nutricional previa al ejercicio sería más apropiada y segura en esta población. En conformidad con los ítems de Informe Preferido para Revisiones Sistemáticas y Meta-análisis (PRISMA), dos investigadores llevaron a cabo, de forma independiente, una búsqueda sistemática y observaron divergencia; y un tercer investigador participó en la selección de artículos. Se seleccionaron dos estudios, y ambos sugieren que la comida de bajo índice glucémico es la mejor opción antes del ejercicio; uno de ellos sugiere que el tiempo antes de la ingesta de alimentación adecuada es de 30 minutos. Sin embargo, estos resultados no son suficientes para definir una conducta clínica y se necesitan otros estudios para dilucidar si I G es un parámetro relevante para el monitoreo clínico del paciente con diabetes mellitus (DM), durante y después del ejercicio, principalmente en relación con las diferentes orientaciones de DM tipo 1 y tipo 2. Nivel de evidencia Il; Estudio Pronóstico.

Descriptores: Diabetes mellitus; Ejercicio aeróbico; Conducta alimenticia; Carbohidratos; Indice glucémico; Hipoglucemia. 


\section{INTRODUCTION}

Diabetes mellitus (DM) is a disease characterised by chronic hyperglycaemia, secondary to insufficient production of insulin by the $\beta$ cells of the pancreas (type $1 \mathrm{DM}$ ), the ineffective action of this hormone (type 2 DM) or both. ${ }^{1,2}$

The global population with DM is currently estimated to be 387 million, and is expected to reach 471 million in 2035. 'This increase is due to many factors such as population growth and aging, increased urbanisation, advances in disease treatment resulting in greater survival, and especially, the increased prevalence of obesity and sedentary lifestyles. ${ }^{1}$

Obesity and physical inactivity are the main risk factors for type 2 DM, and with established disease, these become the focus of non-pharmacological treatment, in order to control hyperglycaemia. ${ }^{3-5}$

In combatting obesity, changing the quality of the carbohydrate during feeding rather than the amount ingested has emerged as a better strategy for glycaemic control. ${ }^{6}$ From this perspective, the glycaemic index (GI) of food becomes an option for the control of diet quality, and has been considered a relevant parameter for clinical monitoring of the patient with DM. ${ }^{7,8}$

Regarding sedentary lifestyle, exercise, especially aerobic, has emerged as an excellent strategy to control postprandial blood glucose peaks, by making the body preferentially use the meal-derived glucose for carrying out the proposed activity. ${ }^{9,10}$

The individual benefits of these two strategies are relevant; however, when evaluated together, it is important to consider that the greatest risk in exercise training for a patient with DM is hypoglycaemia, ${ }^{1}$ which can transform a healthy practice into an activity that could ultimately be damaging to your health. Therefore, according to the characteristics of the exercise to be performed, it is essential to pay attention to prior food intake. ${ }^{2}$ Thus, the aims of this study were 1) to conduct a systematic review of the glycaemic index of the pre-exercise meal and of glycaemic behaviour during and after aerobic exercise in diabetics and 2) to discuss what pre-exercise nutritional guidance would be more appropriate and safe in this population.

\section{METHODS}

For this review, the Preferred Reporting Items for Systematic Review and Meta-Analyses (PRISMA) were observed. ${ }^{11}$

\section{Search strategy}

Two researchers independently performed a systematic search for articles that addressed the issue of the glycaemic index of the pre-exercise meal and glucose metabolism in DM, as there was divergence, a third researcher participated of the selection of articles. The search for articles was based on the Medline database by combining the following MeSH keywords: aerobic exercise, glycaemic index, blood glucose and diabetes mellitus. Clinical trials and sample populations were used as search filters. Exclusion criteria were articles that used exercise without aerobic predominance and those that included non-diabetic individuals.

\section{RESULTS}

Figure 1 shows the stages of the adopted search strategy, the justification of the exclusions of some studies during the process and the total number of articles selected for analysis. Due to the initial divergence of the number of articles selected, it was necessary to perform an analysis with a third researcher.

The methodological characteristics and the main results of the glycaemic behaviour of the two articles selected for analysis are presented in Table 1.

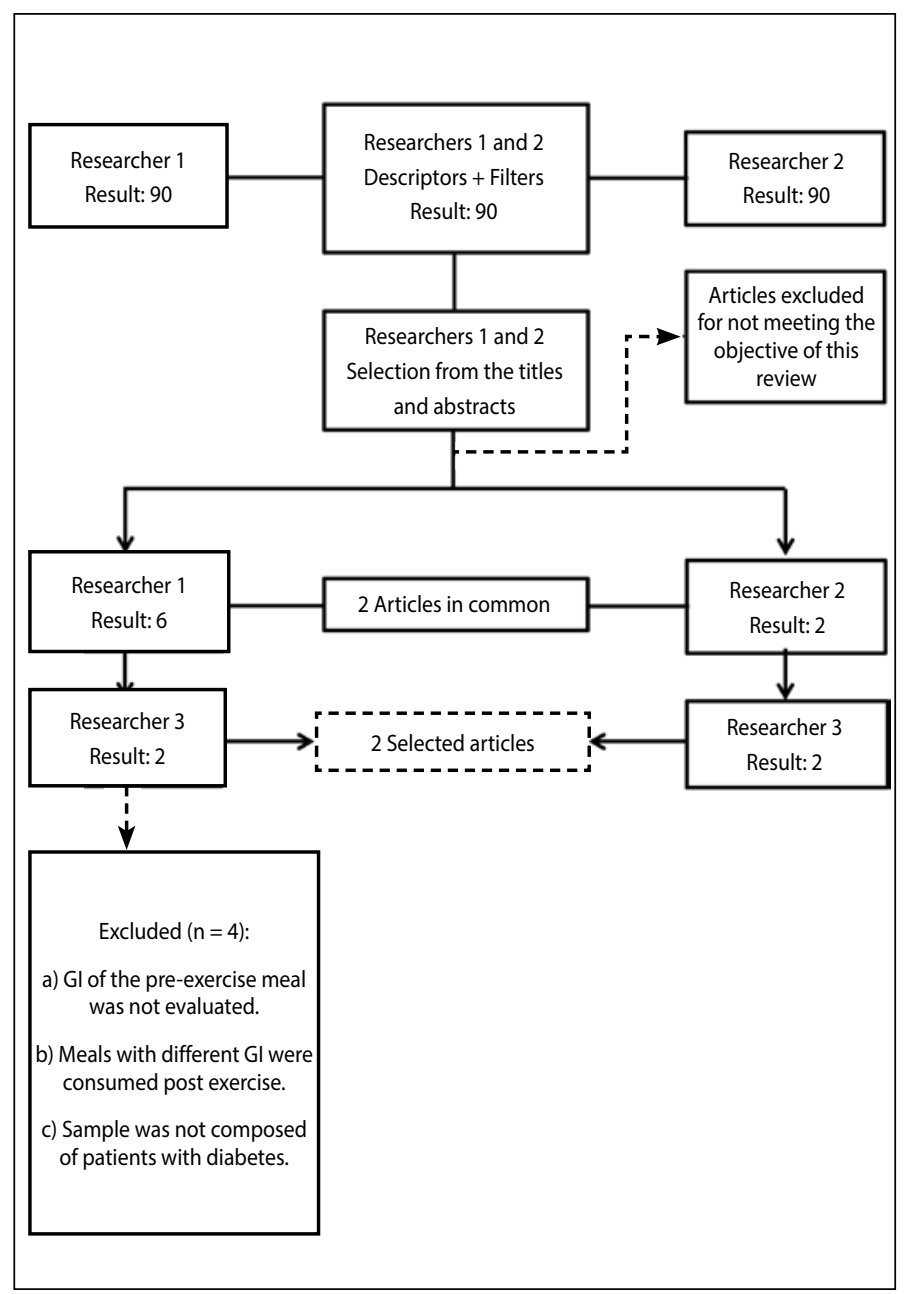

Figure 1. Flowchart of the search strategy.

\section{DISCUSSION}

It is well established in the literature that physical exercise is one of the non-pharmacological strategies to prevent and treat $\mathrm{DM},{ }^{14}$ and for exercise to be safely attempted without the occurrence of hypoglycaemia, prior supplementation with a carbohydrate base is recommended. ${ }^{15}$ The Gl appears as a useful and reliable tool in planning the pre-exercise meal, because the $\mathrm{Gl}$ of the food reflects the postprandial glycaemic response. ${ }^{16}$ This index is categorised into low $\mathrm{Gl}(\mathrm{LGl})(<55)$, moderate $\mathrm{Gl}$ (MGI) (56-70) and high GI (HGI) (70-100), differing by absorption speed and glycaemic stability. ${ }^{17}$

The objective of this review was to discuss the ways in which pre-exercise nutritional strategy could be made safer and more appropriate for those with diabetes with respect to the Gl concept. However, even without restricting the publication period, the number of studies addressing this issue remained limited. This was due to the fact that most articles found from the search strategy did not contain the main points of the question of this review: composition of the pre-exercise meal and glycaemic behaviour during and after aerobic exercise; this resulted in only two articles being appropriate for analysis.

These studies ${ }^{12,13}$ suggested that the LGI meal is the best pre-exercise option ${ }^{12,13}$ and that the time for adequate food intake is 30 minutes prior to exercise, ${ }^{13}$ indicating that this nutrition strategy is more suitable for glycaemic control of patients with DM during and after exercise. These results are in agreement with previous studies conducted by part our research group, however, evaluating healthy individuals. ${ }^{18,19}$

As recommended by studies about nutritional care in glycaemic control of DM, ${ }^{20,21}$ West et al. ${ }^{13}$ adopted an LGI meal as a pre-exercise food 


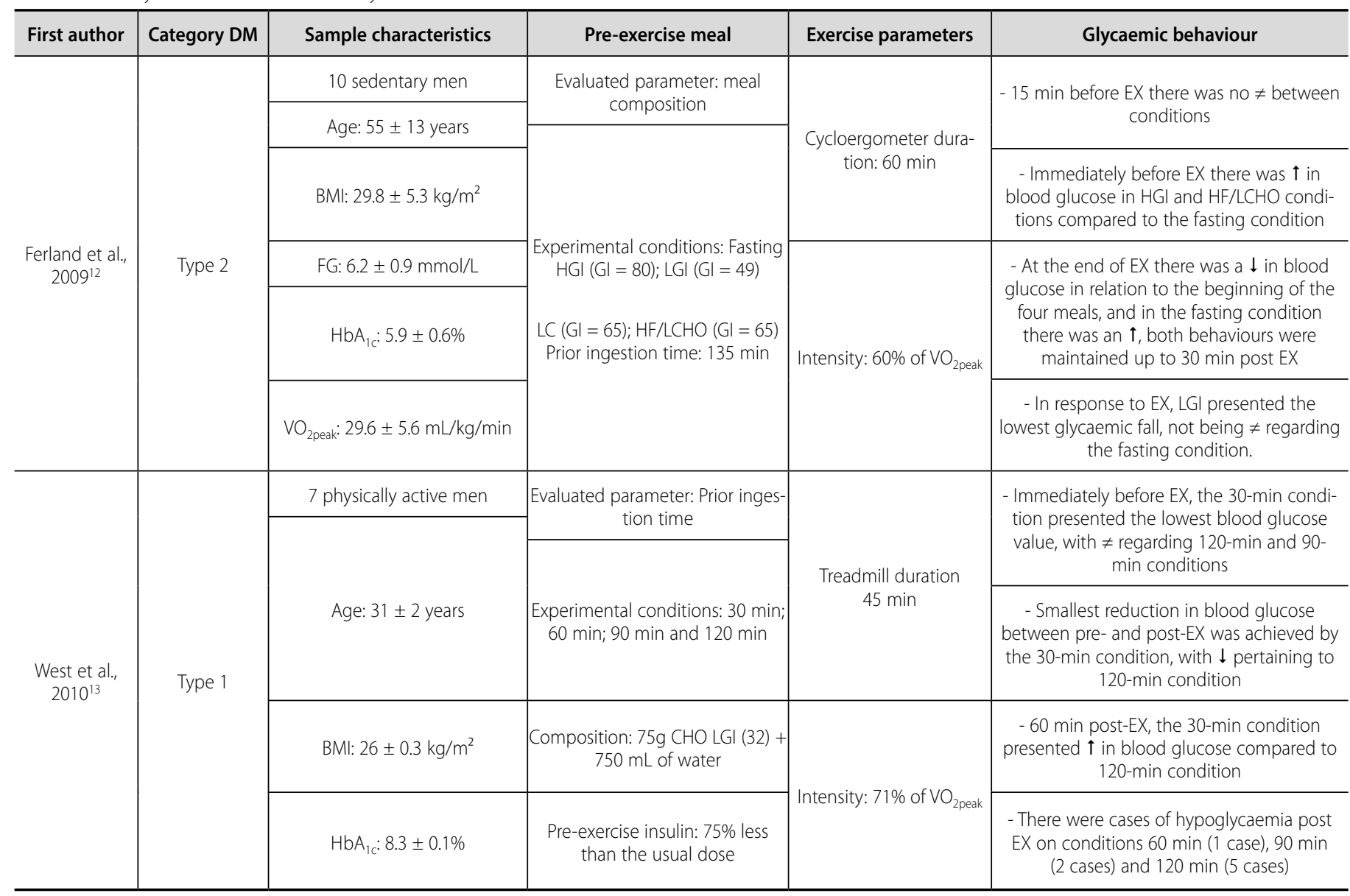

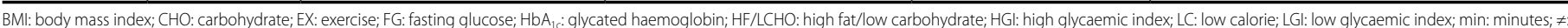
significant difference; $\uparrow$ : significant increase; $\downarrow$ : significant reduction.

strategy. The sample of this study ${ }^{13}$ was composed of individuals with type $1 \mathrm{DM}$; people in this category have a higher risk of hypoglycaemia associated with exercise, ${ }^{2}$ which was found in the 60-min, 90-min and 120-min periods after exercise in experimental conditions. This behaviour can be explained by the lengthy without-food-intake period associated with high glucose uptake as a consequence of exogenous insulin and the action of the GLUT 4 receptors, translocated to membrane muscle cells in response to exercise. ${ }^{17,22,23}$

In a study by Ferland et al. ${ }^{12}$ the sample was composed of individuals with type $2 \mathrm{DM}$, and unlike the previous study, for the more extensive food intake time was adopted before exercise (135 min), and the study did not report any cases of hypoglycaemia. This behaviour may have occurred due to inefficiency of insulin action, characteristic of people in this category ${ }^{1,2}$, and because the population in the sample had been advised not to make use of oral hypoglycaemics the morning of the exercise session (50\% of the sample). Even though this methodological orientation facilitated glycaemic control, the LGI meal presented the lowest initial glycaemic value and less decline after exercise, remaining more stable.

Recent studies show the benefits of different types of physical exercise and highlight LGI foods as part of the nutritional intervention in individuals with type 2 DM. ${ }^{24,25}$ In contrast, in recent studies of exercise and DM type 1, pre-exercise food Gl is not clearly considered as a nutritional care option for glycemic control during physical exercise. 26,27 This current view may reflect that the relevance of $\mathrm{Gl}$ to clinical practice is not yet clear.
The selected studies ${ }^{12,13}$ differ in various methodological aspects, such as category of DM, physical status of the pre-exercise meal, ergometer used, duration and intensity of exercise, age and fitness of participants, and restriction to male sex. All of these factors influence the interpretation of the results and prevent the generalisation of these conclusions to the entire population with DM. Given this and because they are only two studies, we can highlight as limitation of our study the use of only one database, restricting the number of articles available for analysis.

However, we suggest that further studies should be conducted to elucidate whether $\mathrm{Gl}$ is a relevant parameter for clinical monitoring of the patient with DM during exercise, especially in relation to different guidelines for individuals with type 1 and type 2 DM.

\section{CONCLUSIONS}

Although LGI meal offered 30 min before aerobic exercise seems to be a proper and safe nutritional intervention for glycaemic behaviour, these results are not sufficient to define a clinical conduct.

\section{ACKNOWLEDGMENTS}

The authors would like to thank the support of the Pro-Rectory of Research of the Universidade Federal de Minas Gerais and PROEX/CAPES.

All authors declare no potential conflict of interest related to this article. 


\section{REFERENCES}

1. Sociedade Brasileira de Diabetes. Diretrizes da Sociedade Brasileira de Diabetes 2015-2016, A.C. São Paulo: Farmacêutica; 2016. p. 337.

2. American Diabetes Association. Standards of Medical Care in Diabetes - 2017. Diabetes Care. 2017;40(1):S1-S135

3. Carolan-Olah MC. Educational and intervention programmes for gestational diabetes mellitus (GDM) management: An integrative review. Collegian. 2016;23(1):103-14.

4. van Dijk JW, Eijsvogels TM, Nyakayiru J, Schreuder THA, Hopman MT, Thijssen DH, et al. Glycemic control during consecutive days with prolonged walking exercise in individuals with type 1 diabetes mellitus. Diabetes Res Clin Pract. 2016;117:74-81.

5. Watson N, Dyer K, Buckley J, Brinkworth G, Coates A, Parfitt G, et al. Effects of low-fat diets differing in protein and carbohydrate content on cardiometabolic risk factors during weight loss and weight maintenance in obese adults with type 2 diabetes. Nutrients. 2016;8(5):289.

6. García-Prieto CF, Fernández-Alfonso MS. Caloric Restriction as a strategy to improve vascular dysfunction in metabolic disorders. Nutrients. 2016;8(6):1-18.

7. Augustin LSA, Kendall CWC, Jenkins DJA, Willett WC, Astrup A, Barclay AW, et al. Glycemic index glycemic load and glycemic response: An International Scientific Consensus Summit from the International Carbohydrate Quality Consortium (ICQC). Nutr Metab Cardiovasc Dis. 2015,25(9):795-815.

8. Naser KA, Wimalawansa SJ. Diabetes Diet: Is glycemic index still relevant in medical nutrition therapy? SRL Diabetes \& Metabolism. 2015;1(1):1-4.

9. Chacko E. Exercising tactically for taming postmeal glucose surges. Scientifica. 2016;2016:1-10.

10. Chacko E. Why exercise before breakfast may not be for diabetes patients. Conn Med. 2014;78(9):517-20

11. Liberati A, Altman DG, Tetzlaff J, Mulrow C, Gotzsche PC, loannidis JP, et al. The PRISMA statement for reporting systematic reviews and meta-analyses of studies that evaluate health care interventions: Explanation and elaboration. PLOS Medicine. 2009;6(7):e1000100.

12. Ferland A, Brassard P, Lemieux S, Bergeron J, Bogaty P, Bertrand F, et al. Impact of high-fat/low-carbohydrate, high-, low-glycaemic index or low-caloric meals on glucose regulation during aerobic exercise in Type 2 diabetes. Diabet Med. 2009;26(6):589-95

13. West DJ, Stephens JW, Bain SC, Kilduff LP, Luzio S, Still R, et al. A combined insulin reduction and carbohydrate feeding strategy 30 min before running best preserves blood glucose concentration after exercise through improved fuel oxidation in type 1 diabetes mellitus. J Sports Sci. 2011;29(3): 279-89.
14. Riddell MC, Miadovnik L, Simms M, Li B, Zisser H. Advances in exercise, physical activity, and diabetes mellitus. Diabetes Technol Ther. 2013;15(Suppl 1):S96-106.

15. Dubé MC, Lavoie C, Galibois I, Weisnagel SJ. Nutritional strategies to prevent hypoglycemia at exercise in diabetic adolescents. Med Sci Sports Exerc. 2012;44(8):142-32.

16. Foster-Powell K, Holt SHA, Brand-Miller JC. International table of glycemic index and glycemic load values: 2002. Am J Clin Nutr. 2002;76(1):5-56

17. Jeukendrup $A E$, Killer SC. The myths surrounding pre-exercise carbohydrate feeding. Ann Nutr Metab. 2010;57(Suppl 2):18-25.

18. Faria VC, Marins JCB, Oliveira GA, Sales SS, Reis FF, Pereira JC, et al. Metabolic response to different glycemic indexes of pre-exercise meal. Rev Bras Med Esporte. 2015;21(4):287-91.

19. Faria VC, Oliveira GA, Sales SS, Marins JCB, Lima LM. Índice glicêmico da refeição pré-exercício e metabolismo da glicose na atividade aeróbica. Rev Bras Med Esporte. 2014;20(2):156-60.

20. Louie JCY, Markovic TP, Ross GP, Foote D, Brand-Miller JC. Timing of peak blood glucose after breakfast meals of different glycemic index in women with gestational diabetes. Nutrients. 2013;5(1):1-9.

21. Li D, Zhang P, Guo H, Ling W. Taking a low glycemic index multi-nutrient supplement as breakfast improves glycemic control in patients with type 2 diabetes mellitus: a randomized controlled trial. Nutrients. 2014;6(12):5740-55.

22. Mondazzi L, Arcelli E. Glycemic index in sport nutrition. J Am Coll Nutr. 2009;28(Suppl 4):455S-63S.

23. Sylow L, Kleinert M, Richter EA, Jensen TE. Exercise-stimulated glucose uptake - regulation and implication for glycaemic control. Nat Rev Endocrinol. 2017;13(3):133 - 48.

24. Barreira E, Novo A, Vaz JA, Pereira AMG. Dietary program and physical activity impact on biochemical markers in patients with type 2 diabetes: A systematic review. Aten Primaria. 2017; Article in press.

25. Jiang X, Fan X, Wu R, Geng F, Hu C. The effect of care intervention for obese patients with type II diabetes. Medicine (Baltimore). 2017;96(42):e7524

26. Mascarenhas LPG, Decimo JP, Lima VA, Kraemer GC, Lacerda KRC, Nesi-França S. Physical exercise in type 1 diabetes: recommendations and care. Motriz: rev educ fis. 2016;22(4):223 - 30

27. Francescato MP, Stel G, Stenner E, Geat M. Prolonged Exercise in Type 1 Diabetes: Performance of a Customizable Algorithm to Estimate the Carbohydrate Supplements to Minimize Glycemic Imbalances. Plos One. 2015;10(4):e0125220. 